\title{
PENGARUH THERAPY BEKAM BASAH TERHADAP TEKANAN DARAH PASIEN HIPERTENSI
}

\author{
Leli Mulyati, Surani, Marisa
}

\author{
Poltekkes Bengkulu Prodi Keperawatan Curup, Jl. Sapta Marga.95 Curup
}

\begin{abstract}
This study aims to determined the effected of wet cupping therapy on blood pressure in hypertensive patients. The study used a quasi-experimental method with one group pre-test and post-test without a control group. The study subjects total 30 respondents consisting of patients with hypertension. All subjects are given wet cupping treatment twice with an interval of 2 weeks. Blood pressure measurements made before and after wet cupping. The results of analysis used a tdependent, decrease in average systolic blood pressure was $13333 \pm 12042$ wet cupping $\mathrm{mmHg}$ and diastolic $4667 \pm 3294 \mathrm{mmHg}$. At week 2 a decrease in average systolic blood pressure $\mathrm{mmHg}$ while the $8667 \pm 83086667 \pm 5525 \mathrm{mmHg}$ diastolic. Decrease in average systolic and diastolic blood pressure there were significant differences $(\mathrm{p}<0.05)$ in the first wet cupping and second wet cupping. This shows that wet cupping therapy affects blood pressure in hypertension patients.
\end{abstract}

Keywords: hypertension, blood pressure, cupping therapy

\begin{abstract}
Abstrak : Penelitian ini bertujuan untuk mengetahuai pengaruh terapi bekam basah terhadap tekanan darah pada penderita hipertensi. Penelitian ini menggunakan metode quasi eksperimen dengan one group pre-test dan post-test tanpa group kontrol. Subyek penelitian berjumlah 30 responden yang terdiri dari penderita hipertensi. Semua subyek diberikan perlakuan bekam basah sebanyak dua kali dengan interval waktu 2 minggu. Pengukuran tekanan darah dilakukan sebelum dan sesudah dilakukan bekam basah. Hasil analisis menggunakan $t$ dependen, penurunan rata-rata untuk tekanan darah sistolik sekali bekam basah $13.333 \pm 12.042 \mathrm{mmHg}$ dan diastol $4.667 \pm 3.294$ mmHg. Pada minggu ke 2 terjadi penurunan rata-rata tekanan darah sistol $8.667 \pm 8.308 \mathrm{mmHg}$ sedangkan diastol $6.667 \pm 5.525 \mathrm{mmHg}$. Penurunan rata-rata tekanan darah sistol dan diastol terdapat perbedaan yang bermakna $(\mathrm{p}<0,05)$ pada bekam basah pertama maupun bekam basah yang ke dua. Hal ini menunjukkan terapi bekam basah mempengaruhi tekanan darah pada penderita hipertensi.
\end{abstract}

Kata kunci: hipertensi, tekanan darah, terapi bekam.

Penyakit hipertensi menimbulkan angka kesakitan dan kematian yang tinggi. Penyakit hipertensi merupakan penyakit yang timbul akibat adanya interaksi dari berbagai faktor resiko yang dimiliki seseorang. Berbagai penelitian telah menghubungkan antara berbagai faktor resiko terhadap timbulnya hipertensi. berdasarkan penelitian yang telah dilakukan ternyata angaka kejadian hipertensi meningtkat dengan bertambahnya usia.

Menurut Kemenkes RI (2010), bahwa hipertensi merupakan penyebab kematian nomor 3 setelah stroke dan tuberkulosis, yakni mencapai $6,7 \%$ dari populasi kematian pada semua umur di Indonesia (Cekly, 2011).

Berdasarkan Data dari Dinas Kesehatan Rejang Lebong jumlah penderita hipertensi cenderung meningkat. Pada tahun 2007 adalah 3891 orang dengan prevalensi 7,1\%, tahun 2008 adalah 4641 orang dengan prevalensi 8,9\%, tahun 2009 sebanyak 5352 orang dan tahun 2010 adalah 6405 (Profil DinKes Rejang Lebong, 2010).

Data awal penderita hipertensi berdasarkan Profil Dinkes Rejang Lebong di Puskesmas Perumnas tahun 2010 berjumlah 1307, sedangkan catatan grafik bulanan kunjungan pasien di Puskesmas Perumnas sendiri dari bulan januari hingga oktober 2011 berjumlah 1341 (Grafik bulan Puskesmas Perumnas, 2011)

Terapi farmakologi terkadang dapat menimbulkan beberapa efek yang membahayakan dan cenderung tidak aman jika diberikan dalam jangka waktu yang lama 
sehingga diperlukan adanya metode terapi baru untuk mengatasinya salah satunya adalah dengan terapi bekam (Taufik, 2010).

Cupping (bekam) merupakan metode pengobatan klasik yang telah digunakan dalam perawatan dan pengobatan berbagai masalah kesehatan di antaranya Penyakit darah seperti hemofili dan hipertensi, Penyakit reumatik mulai dari artritis, sciatica/nyeri panggul, sakit punggung, migren, gelisah/anxietas dan masalah fisik umum maupun mental. Tujuan bekam adalah untuk membuang darah dari dalam tubuh yang diyakini dapat merusak tubuh dan pada gilirannya berpotensi merugikan mulai dari gejala biasa sampai yang mengarah pada menurunnya derajat kesehatan (Hana, 2007). Hal ini menunjukkan terapi bekam dapat menurunkan tekanan darah pada pasien hipertensi. Tujuan penelitian ini adalah untuk mengidentifikasi pengaruh terapy bekam basah terhadap tekanan darah pasien hypertensi.

\section{BAHAN DAN CARA KERJA}

Desain pada penelitian ini menggunakan pre Eksperimental dengan metode penelitian menggunakan rancangan One Group Pretest-Posttest. Proses terapi bekam basah dilakukan sebanyak 2 kali pada setiap responden dengan rentang waktu antara intervensi I dan II selama 2 minggu. Titik pembekaman yang digunakan adalah 5 titik yaitu 2 al-akhdain, 1 al-khahil, 2 al-katifain.

Populasi penelitian ini adalah semua pasien hipertensi yang tercatat di Puskesmas Perumnas Curup Bengkulu. Teknis pengambilan sampel ini menggunakan teknik Consecutive sampling. Jumlah sampel penelitian ini adalah 30 sampel .

\section{HASIL}

Analisis univariat

Tabel 1. Karakteristik Responden Pada Penderita Hipertensi di Wilayah Kerja Puskesmas Perumnas Tahun 2012

\begin{tabular}{lccccc}
\hline $\begin{array}{c}\text { Karak } \\
\text { teristik }\end{array}$ & Mean & $\begin{array}{c}\text { Medi } \\
\text { an }\end{array}$ & $\begin{array}{c}\text { Mo } \\
\text { dus }\end{array}$ & $\begin{array}{c}\text { Mini } \\
\text { mum }\end{array}$ & $\begin{array}{c}\text { Maksi } \\
\text { mum }\end{array}$ \\
\hline Usia & 53 & 53,5 & 58,5 & 34 & 80 \\
Lama & 9,7 & 8 & 5,5 & 1 & 30 \\
Hipertensi & & & & & \\
\hline
\end{tabular}

Berdasarkan tabel 1. Diketahui bahwa rata-rata usia responden adalah 53 tahun (usia lanjut awal), lama mengalami hypertensi rata-rata 9,7 tahun (hypertensi kronis).

\section{Analisis bivariat}

Berdasarkan tabel 2 didapat hasil bahwa rata-rata tekanan darah yang terjadi jika dilakukan terapi bekam basah sebanyak satu kali bekam basah pertama tekanan sistol pre dan post bekam basah adalah 13.333. sedangkan tekanan diastol pre dan post bekam basah adalah 4.667 serta berdasarkan analisis bivariat $T$ Test dependent didapatkan hasil bahwa $t$ pada tekanan sistol pre dan post bekam basah I adalah $12.042 \mathrm{mmHg}$, tekanan diastol pre dan post bekam basah $t$ hitung $=3.294$ $\mathrm{mmHg}$, Serta di dapatkan nilai $\mathrm{P}$ pada tekanan sistol pre dan post bekam basah $\mathrm{P}=0.000$, tekanan diastol pre dan post bekam basah $\mathrm{P}=0.003$, maka Ha gagal ditolak artinya ada pengaruh, terapi bekam basah Intervensi I terhadap penurunan tekanan darah pada penderita hipertensi.

Tabel.2 Pengaruh Terapi Bekam Basah Intervensi I Terhadap Tekanan Darah Pada Penderita Hipertensi Di Wilayah Kerja Puskesmas PerumnaTahun 2012

\begin{tabular}{|c|c|c|c|c|c|c|c|c|}
\hline \multirow{3}{*}{ Intervensi } & \multicolumn{5}{|c|}{ Paired Differences } & \multirow[t]{3}{*}{$t(d f)$} & \multirow[t]{3}{*}{$\mathrm{N}$} & \multirow[t]{3}{*}{ Pvalue } \\
\hline & \multirow[t]{2}{*}{ Mean } & \multirow[t]{2}{*}{ SD } & \multirow[t]{2}{*}{$\mathrm{SE}$} & \multicolumn{2}{|c|}{$95 \% \mathrm{CI}$} & & & \\
\hline & & & & Lower & Upper & & & \\
\hline Pre_sistol-post_sistol & 13.333 & 6.065 & 1.107 & 11.069 & 15.598 & 12.042 & 30 & 0.000 \\
\hline Pre_diastol-post_diastol & 4.667 & 7.761 & 1.417 & 1.769 & 7.565 & 3.294 & 30 & 0.003 \\
\hline
\end{tabular}


Tabel 3. Pengaruh Terapi Bekam Basah Intervensi 2 Terhadap Tekanan Darah Pada Penderita Hipertensi Di Wilayah Kerja Puskesmas Perumnas

\begin{tabular}{|c|c|c|c|c|c|c|c|c|}
\hline \multirow[t]{3}{*}{ Intervensi } & \multicolumn{5}{|c|}{ Paired Differences } & \multirow[t]{3}{*}{$t(d f)$} & \multirow[t]{3}{*}{$\mathrm{n}$} & \multirow[t]{3}{*}{$P$ Value } \\
\hline & \multirow[t]{2}{*}{ Mean } & \multirow[t]{2}{*}{ SD } & \multirow[t]{2}{*}{$\mathrm{SE}$} & \multicolumn{2}{|c|}{$95 \% \mathrm{CI}$} & & & \\
\hline & & & & Lower & Upper & & & \\
\hline Pre_sistol-post_sistol & 8.667 & 5.713 & 1.043 & 6.533 & 10.800 & 8.308 & 30 & 0.000 \\
\hline Pre_diastol-post_diastol & 6.667 & 6.609 & 1.207 & 4.199 & 9.134 & 5.525 & 30 & 0.000 \\
\hline
\end{tabular}

Dari Tabel 3 diatas rata-rata tekanan darah sistol pada bekam ke dua pre dan pos bekam adalah 8.667 dan rata-rata tekanan darah diastol pre dan post bekam 6.667 . Adapun tekanan darah sistol pada bekam ke dua pre dan pos bekam $t$ hitung $=8.308$ $\mathrm{mmHg}$ dan nilai $t$ pada tekanan darah diastol pre dan post bekam adalah 5.525 mmHg. tekanan darah sistol pada bekam ke dua pre dan pos bekam $\mathrm{P}=0.000$ dan pada tekanan darah diastol pre dan post bekam P hitung $=0.000<\alpha=0.05$, maka Ha gagal ditolak artinya ada pengaruh terapi bekam basah Intervensi 2 terhadap penurunan tekanan darah pada penderita hipertensi

\section{PEMBAHASAN}

Mean Tekanan Darah Systolik Dan Dyastolik Sebelum Dan Setelah Di Lakukan Intervensi Bekam

Hasil rata-rata tekanan darah sistol pre bekam basah pertama 165.00 dan post bekam basah 151.67 sedangkan untuk ratarata tekanan darah diastol pre bekam basah 106.67 dan pada post bekam 102.00, Dengan nilai d Mean (selisih rata-rata) tekanan darah sistol pre dan post bekam basah 13.33 sedangkan selisih rata-rata diastol adalah 4.67. Sedangkan intervensi bekam basah ke dua didapatkan rata-rata tekanan darah sistol 151.67 dan post bekam basah 143.00 sedangkan rata-tata tekanan darah diastol pada pre bekam basah 101.67 dan post bekam basah 95.00 dengan niali d Mean sistol 8.67 dan diastol 6.67 .

Menurut Umar (2006) mekanisme kerja terapi bekam terjadi di bawah kulit dan otot yang terdapat banyak titik saraf. Titik-titik ini saling berhubungan antara organ tubuh satu dengan lainnya sehigga bekam dilakukan tidak selalu pada bagian tubuh yang sakit namun pada titik simpul saraf terkait.

Pembekaman biasanya dilakukan pada permukaan kulit (kutis), jaringan bawah kulit (sub kutis) jaringan ini akan "rusak". Kerusakan disertai keluarnya darah akibat bekam akan ikut serta keluar beberapa zat berbahaya seperti serotonin, bistamin, bradiknin dan zat-zat berbahaya lainnya. Bekam juga menjadikan mikrosirkulasi pembuluh darah sehingga timbul aefek relaksasi pada otot sehingga dapat menurunkan tekanan darah (Mulyati, 2011)

\section{Pengaruh Therapy Bekam Basah Terhadap Tekanan Darah Pasien Hipertensi Di Puskesmas Perumnas}

Penelitian ini menggunakan uji $T$ Test dependen (paired sampels t-test) dengan syarat/asumsi yang harus dipenuhi dalam penelitian ini sendiri yaitu data berdistribusi normal/simetris, kedua kelompok data dependen, variabel yang dihubungkan berbentuk numerik untuk variabel dependen dan kategori dengan hanya dua kelompok untuk variabel independen. Berdasarkan analisis bivariat $T$ Test dependen didapatkan hasil bahwa $t$ hitung pada tekanan sistol pre dan post bekam basah adalah 12.042, tekanan diastole pre dan post bekam $t$ hitung $=$ 3.294, tekanan darah sistolik pada bekam ke dua pre dan pos bekam $t$ hitung $=8.308$ dan nilai $t$ pada tekanan darah diastol pre dan post bekam adalah 5.525. Serta di dapatkan nilai $\mathrm{P}$ pada tekanan sistol pre dan post bekam $\mathrm{P}=.000$, tekanan diastole pre dan post bekam $\mathrm{P}=0.003$, tekanan darah sistolik pada bekam ke dua pre dan 
pos bekam $\mathrm{P}=.000$ dan pada tekanan darah diastol pre dan post bekam $\mathrm{P}$ hitung $=.000<\alpha=0.05$, maka Ha gagal ditolak artinya ada pengaruh terapi bekam basah terhadap penurunan tekanan darah pada penderita hipertensi.

Hasil penelitian ini sejalan dengan pernyataan Purwandari, (2010) bahwa terjadi penurunan rata-rata tekanan darah sistolik pada sekali pembekaman sebesar $14,6 \pm 12,823 \mathrm{~mm} \mathrm{Hg}$ dan tekanan darah diastolik sebesar 2,6 $\pm 10,012 \mathrm{~mm} \mathrm{Hg}$. Pada kelompok minggu ke-2 terjadi penurunan rata-rata tekanan darah sistolik sebesar 16,00 mm Hg $\pm 10,000 \mathrm{~mm} \mathrm{Hg}$ dan tekanan darah diastolik sebesar 1,40 $\pm 9,845 \mathrm{~mm} \mathrm{Hg}$. Penurunan rata-rata tekanan darah sistolik terdapat perbedaan yang bermakna $(\mathrm{p}<0,05) \quad$ sedangkan penurunan rata-rata tekanan darah diastolik menunjukkan perbedaan yang tidak bermakna $(p>0,05)$ pada pembekaman sekali dan pembekaman dua mingu kemudian. Hal ini menunjukkan terapi bekam dapat menurunkan tekanan darah pada pasien hipertensi khususnya pada tekanan sistolik. Hasil penelitian ini

\section{DAFTAR RUJUKAN}

Ahmad, (2010). Modul pelatihan Holistik bekam.Tidak dipublikasikan.

Black, J, \& Hawks,J. (2005). Medical surgical nursing. $\left(7^{\text {th }}\right.$ ed). St louis: Elsevier Saunders

Brown,D \& Edward,H.(2005). Lewi's medical surgical nursing, Australia; Elsevier.

Cekly, (2011). Hubungan gaya hidup dengan kejadian hypertensi pada usia lanjut, diunduh tanggal 14 November 2011 dari http:// mulyiply.com

Friel,C.M. (2000). Measuring reliability. USA: Sam Houston State University

Ignatavicius, D, \& Workman,. (2006). Medical surgical nursing : Critical thinking for collaborative care. 5th ed. St Louis, Missouri: Elsevier Inc.

LeMone, P, \& Burke .(2008). Medical surgical nursing : Critical thinking in client care.( 4th ed). Pearson Prentice Hall: New Jersey. menunjukan terdapat perbedaan bermakna baik tekanan sistolik maupun terkanan diastolik.

Manfaat bekam basah lebih efektif untuk pengobatan karena penyakit pembendungan aliran darah (Umar, 2008), selain itu juga pengeluaran volume darah dan vasodilatasi kapiler dan arteriol yang berpengaruh terhadap penurunan tekanan darah (Yassin, 2007).

\section{KESIMPULAN}

Berdasarkan hasil penelitian rata-rata usia responden adalah 53 tahun (usia lanjut awal), lama mengalami hypertensi rata-rata 9,7 tahun (hypertensi kronis).

Rata-rata tekanan darah sistol pre bekam basah pertama $165.00 \mathrm{mmHg}$ dan rata-rata intervensi post bekam basah ke dua 143.00 mmHg. Rata-rata tekanan darah diastol pre bekam basah pertama $106.67 \mathrm{mmHg}$ dan rata-rata intervensi post bekam basah ke dua $95.00 \mathrm{mmHg}$. Ada pengaruh terapi bekam basah terhadap penurunan tekanan darah pada penderita hipertensi di wilayah kerja Puskesmas Perumnas tahun 2012.

Mulyati, L, (2011). Modul terapi komplementer Bekam, Poltekkes Kemenkes Bengkulu.

Price, S.\& Wilson . (2002). Pathofisiology. Clinical concepts of desease proceses. Philadelphia: Mosby

Purwandari,A.(2010). Pengaruh terapi bekam terhadap penurunan tekanan darah pada pasien hypertensi. Diunduh tanggal 2 November 2011dari http://digilib.fk.umy.ac.id Smeltzer, S, \& Bare. (2008). Brunner \& Suddarth's Textbook of medical surgical nursing. Philadelpia : Lippincott

Umar, W (2006). Bekam, sembuhkan hypertensi, Migrain,sakit pinggang dan kanker, diunduh tanggal 5 juli 2012 dari http:// wordpress.com

Yassin, SA.(2007).Bekam Sunnah Nabi dan mukjizat Medis.Solo: Al-Qowam 